\title{
モデル動物を用いた鼻過敏症病態の研究
}

一交感神経系の役割について一

入 船 盛 弘

\section{Effect of Sympathetic Denervation in Guinea Pigs with Nasal Hyperreactivity}

\author{
Morihiro Irifune \\ (Osaka University)
}

The effect of sympathetic denervation on nasal hyperreactivity was studied in guinea pigs sensitized by the nasal application of TDI (toluene diisocyanate). Signs and symptoms of nasal hyperreactivity were noted, and histamine assays and histological examination of the nasal mucosa were performed.

In TDI-sensitized guinea pigs the histological appearance of the nasal mucosa suggested type I allergy, but the effect of TDI on the nose as an irritant or its effect on the autonomic nervous system could not be excluded. Unilateral superior cervical ganglionectomy performed before sensitization led to more severe sensitization than in the control group. However, ganglionectomy performed after sensitization resulted in less severe sensitization than in the control group; ganglionectomy had no influence on the histamine content or the histological changes in the nasal mucosa of sensitized guinea pigs 6 weeks after operation.

It was assumed that guinea pigs with nasal hyperreactivity had abnormal autonomic nervous function. We concluded that correction of the abnormality of autonomic regulation in the nose by sympathetic denervation inhibited the nasal hyperreactive symptoms. These experimental results suggest that stellate ganglion block may be effective therapy for nasal hyperreactivity.

Key words: nasal hyperreactivity, model animal, TDI, sympathetic denervation

\section{緒言}

いわゆる鼻過敏症（鼻アレルギーおよび血管 運動性鼻炎を含む）の発症と自律神経系は深く 関係すると考えられているい 鼻過敏症の自律神経面からの治療として主に副 交感神経系のブロックを行う Vidian 神経切断 術5) 7)が行われてきた。，一方，最近はその正反
対とも言える交感神経系をブロックする星状神 経節ブロック ${ }^{8)}$ が新しい治療法として注目され ている. しかし，その有用性，効果機序さらに 適応についてはまだ不明な点が多い.

著者らは鼻過敏症患者に対する全身的な自律 神経機能検査について既に報告9)した。 その結 果，これらの症例では健康人と比べて副交感神 
経機能に差があるとは言えず，交感神経系の機 能元進が考えられ，特に鼻アレルギー患者では 症状発現と全身の交感神経系の機能六進が深く 関係することが示唆された。これらの内容は鼻 過敏症に対する星状神経節ブロック治療の効果 機序を説明するうえで非常に興味ある結果であ った.

そとで鼻過敏症の発症と交感神経系の関係を 検討するため，鼻過敏症の動物モデルとして TDI (2, 4 toluene diisocyanate) 感作モルモッ 卜 $^{10)}$ を用い，過敏症状に対する上頸部交感神経 節切除の影響を観察し，その時の鼻粘膜の組織 学的検索およびヒスタミン含有量の測定を行っ た．そして TDI 感作モルモットにおける気道 過敏性発生の機序についても考察を加えたので 報告する。

\section{材料および方法}

1. 実験動物

Hartley 系の雄モルモット（300～500 g) を用 いた.

2. 実験方法

実験 I

図 1 に示す過程で $10 \%$ TDI 酢酸エチル溶液 をモルモット鼻前庭に塗布し TDI 感作を行っ た。 この方法は田中らの方法 ${ }^{10}$ に booster を加 える方法であり，その詳細については既報11に 示した. 最終の塗布より 1 週後， $5 \%$ TDI 酢 酸エチル溶液の鼻塗布で第 1 回目の誘発を行い, 鼻過敏症状を観察した。観察症状により後述す るスコアをつけ，スコア合計により鼻過敏症を 獲得したか否かを判定した。. 以後, 鼻過敏症が 獲得されるととを感作されるとも表現する.

鼻過敏症を獲得したと判定されたモルモット を $\mathrm{A} ， \mathrm{~B} ， \mathrm{C} の 3$ 群に分けた。 A群では第 1 回 目の誘発後数時間以内に pentobarbital 腹腔内

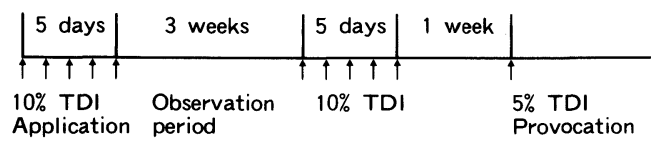

図 1 鼻過敏モルモット作成過程
投与 $(20 \mathrm{mg} / \mathrm{kg})$ 全身麻酔下にて，一側上頸神 経節を切除した。手術方法は頸部正中で縦に皮 膚切開を加え，気管を露出した後その側面より 頸動脈に沿って交感神経節を探索し上頸部の部 分を摘除した。 上頸神経節切除の確認は同側の Horner 症候群の観察によって行った。 即ち 切除側眼瞼下垂, 眼裂の狭小化, 瞳 孔縮小, 眼瞼結膜の充血を確認した。 B 群では sham operation として，上記麻酔下，頸部に単純な 皮切のみを加え縫合した. C群はコントロール として手術操作を加えなかった。

上記操作の 1 週後に再び $5 \%$ TDI で誘発を 行い症状を観察した。その後も週 1 回，計 6 回 同様の誘発，症状の観察を行った。手術操作後 6 週目の最後の誘発, 症状観察ののち心採血に より脱血死させ手術側の鼻粘膜を採取した。 こ れらの鼻粘膜の一部は組織学的検索に，一部 はヒスタミン含有量の測定に配した。同時に TDI 塗布を行っていない正常モルモット 5 匹 について同様に鼻粘膜を採取し組織学的検索, ヒスタミン含有量の測定を行った.

実験 I

正常モルモットを 3 群に分け，D群では実験 $\mathrm{I}$ と同様に一側上頸神経節を切除し， $\mathrm{E}$ 群では 単純な頸部の皮切のみを行い， $\mathrm{F}$ 群では手術操 作を加えなかった。 上記操作ののち 3 日目より これらモルモットに実験 I と同様に 10\% TDI を鼻に塗布し感作を行った. 最終の塗布後 1 週 目に $5 \%$ TDI で誘発を行い，鼻過敏症獲得の 状況を誘発症状で観察した。

3. 症状スコア

表 1 に示すとおり，5\% TDI 誘発後 5 分間

表 1 症状スコア symptom score

\begin{tabular}{|c|c|c|c|c|}
\hline symptom & 0 & 1 & 2 & 3 \\
\hline 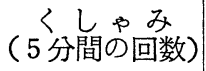 & $(-)$ & $1 \sim 2$ & $3 \sim 5$ & $6 \leqq$ \\
\hline 水様性鼻汁 & $(-)$ & $\begin{array}{l}\text { 鼻入口部 } \\
\text { に見える }\end{array}$ & $\begin{array}{l}1 \text { 中間 } \\
\text { 之 }\end{array}$ & $\begin{array}{l}\text { 鼻外にまで } \\
\text { 流れ落ちる }\end{array}$ \\
\hline 喘 & $(-)$ & 軽くある & $\underset{\text { 中間 }}{1} 3$ の & \begin{tabular}{|l} 
努力性呼吸 \\
学伴う
\end{tabular} \\
\hline
\end{tabular}


の症状観察でスコアをつけた。症状ではくしゃ みの回数, 水様性鼻汁の量, 喘鳴の程度を観察 した．スコア合計が 0 点あるいは 1 点は感作な しとし， 2 点以上を感作ありとし，鼻過敏症を 獲得したと判定した.

\section{4. 鼻粘膜の組織学的検索}

最終誘発後 2 から 6 時間でモルモットを脱血 死させ，頭部を離断，頭蓋を骨縫合に沿って正 中より割断し両鼻腔を露出して手術側の鼻粘膜 を採取した。主に前鼻甲介，鼻中隔を中心に粘 膜を剝離採取した。

固定は10\%ホルマリン，カルノア (Carnoy), カルノフスキー (Karnovsky) の各固定液を使用 した. パラフィン包埋 $4 \sim 6 \mu$ 切片を作成し， 染色方法はへマトキシリン・エオジン，オレン ジエオジン・トルイジンブルー，トルイジンブ ルー単独を行った. これらの標本を光学顕微鏡 にてヒト鼻粘膜に相当する線毛円柱上皮部を中 心に観察した。

\section{5. 鼻粘膜ヒスタミン含有量の測定}

上記の要領にて採取した鼻粘膜の一部を $-80^{\circ} \mathrm{C}$ に保存し， 2 週前後でヒスタミン含有 量を測定した. 方法は Hasegawa らの報告 ${ }^{12}$ に準じ Shore の変法 ${ }^{13)} に て$ 行った，概略につ いては既報 ${ }^{11}$ に示すとおりである.

\section{成 績}

\section{実験 I}

1) 症状スコア

10\%TDI の適用で感作を行った 17 匹のモル

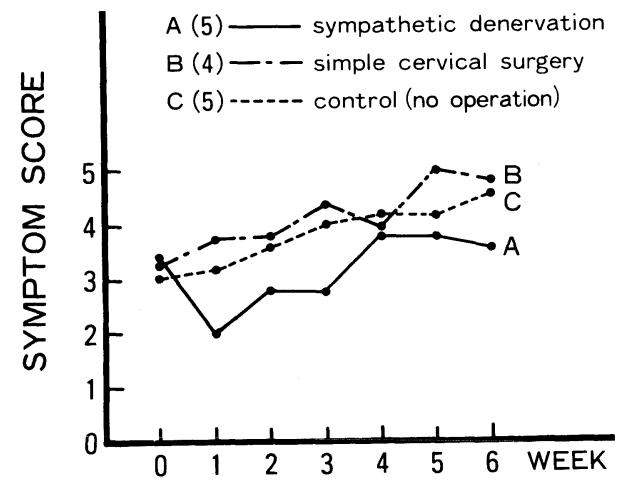

図 2 実験 I. 症状の変化
モットのうち14匹が鼻過敏症を獲得した．A群 5 匹，B群 4 匹，C群 5 匹各群モルモットの症 状スコア合計の平均値の変動を図 2 に示した。 上頸神経節切除の $\mathrm{A}$ 群では 1 週後の誘発では症 状スコアが最も低く，2 週目以後は徐々に上昇 した。一方，単純皮切のみのB群と手術操作を 加えなかったC 群では多少の変動はあるが，週 ごとにスコアは徐々に上昇した。また各時点と も $\mathrm{A}$ 群は B 群， C 群と比べて低いスコアを示し た。しかし週を経るに従いA群と B 群， C群の 差は少なくなる傾向があった。

2 ) 鼻粘膜の組織学的所見

A， B， C 群の TDI 感作モルモット全般に ついては正常モルモットと比較すると以下のよ うな所見を呈した。上皮においては分泌機能の 亢進を思わせる goblet cell の増加や，上皮細胞 の空胞化が目立った，粘膜固有層においては浮 腫傾向，血管の拡張がみられた。鼻腺において は粘液貯留を思わせる濃染および顆粒が認めら れた。

細胞浸潤では著しい好酸球の浸潤と好塩基性 細胞の出現が認められた。主に上皮基底膜およ び固有層上部に多く認められ，一部上皮内に侵 入している部分もあった（図 3 ，図 4)。好塩 基性細胞について特徵的なとととして10\%ホル マリン固定標本ではトルイジンブルーで異染性 を示しにくかったが，カルノアおよびカルノフ スキー固定に括いてはよく異染性を示し判別が 容易であった（図５）。

A， B， C各群のモルモットのほとんどにつ いて上記の所見を認めた。さらに各群間の比較 検討を上皮, 固有層, 細胞浸潤について行った が，明らかな差を認めなかった。

3）鼻粘膜ヒスタミン含有量

表 2 に示すごとく A， B，C群のモルモット は正常モルモットに比較して鼻粘膜ヒスタミン 含有量は有意に高かった $(\mathrm{P}<0.01)$. しかし， $\mathrm{A} ， \mathrm{~B} ， \mathrm{C}$ 各群間では差がなかった。

\section{実験 II}

表 3 に $5 \%$ TDI による初回誘発時の各モル 


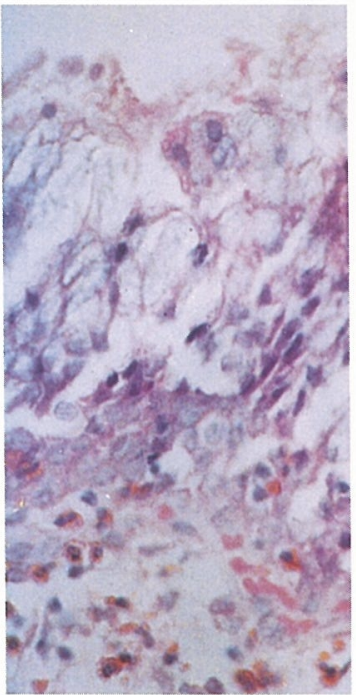

a 上皮層

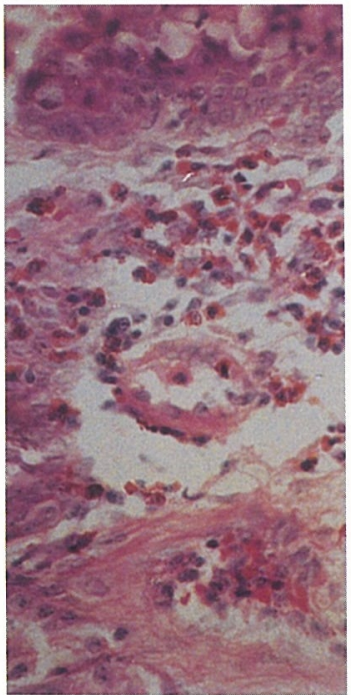

b. 基底層

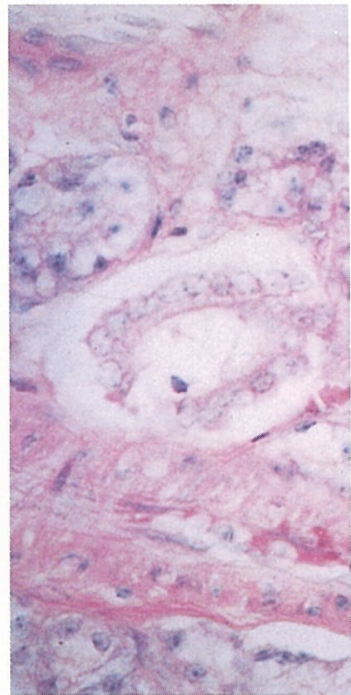

c . 固有層

好酸球の浸潤著しい

図 3 TDI モルモット (C群) の鼻粘膜組織

10\%ホルマリン固定，オレンジエオジン・トルイジンブルー染色 $\times 400$

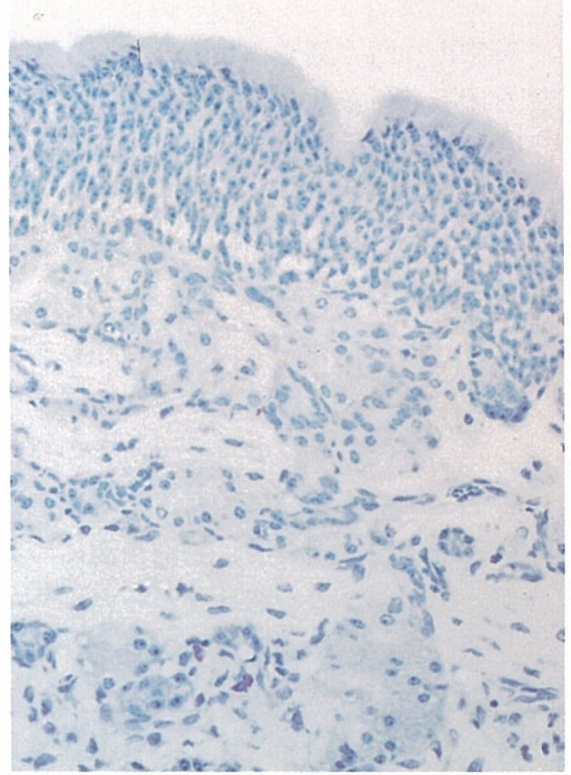

a. 正常モルモット カルノフスキー固定

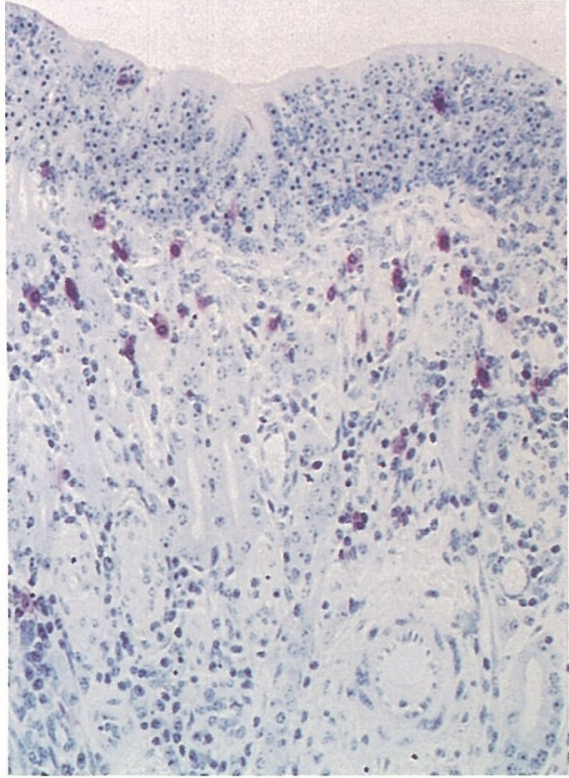

b・TDI モルモット（C群）カルノア固定

図 4 モルモット鼻粘膜組織

トルイジンブルー染色 $\times 200$

b. TDIモルモットで異染性を示す好塩基性細胞の出現あり. 
モットの症状スコア合計を示した。 上頸神経節 切除の D群は 6 例全例上屯 2 点以上で，鼻過敏 症を獲得したよ判定された。一方，単純頸部手 術の $\mathrm{E}$ 群と手術操作を行っていない $\mathrm{F}$ 群では， それぞれ 4 例のうち 2 例だけが 2 点以上であっ た。鼻過敏症を得たモルモットでむ $\mathrm{D}$ 群は $\mathrm{E}$ 群, $\mathrm{F}$ 群に比較してスコアの高い傾向があった。

\section{考察}

＜TDI 感作モルモットについて>

今回の実験で作成した鼻過敏モルモットでの 鼻粘膜の組織学的検索では正常例と比べると明 らかな分泌六進像，上皮直下の好酸球浸潤像， 好塩基性細胞の出現があった。乙れらの点は田 中らの報告 ${ }^{10}$ に一致し，その形態は I 型アレル

表 2 実験 I ・鼻粘膜ヒスタミン含有量

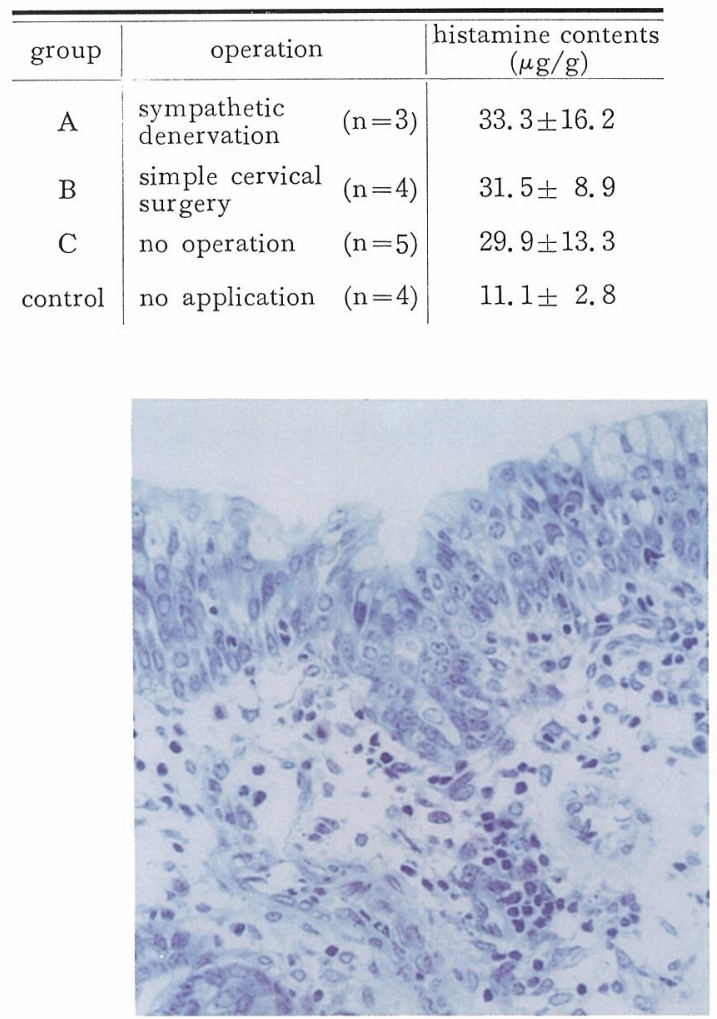

a・ホルマリン固定
ギーの病理所見を示唆するものであった。

鼻粘膜上皮下に出現した好塩基性細胞は10\% ホルマリン固定ではトルイジンブルー染色によ る異染性を示しにくく，アルコールを基剂とす るカルノア固定およびアルデヒドを基片とする

表 3 実験 $\square$. 初回誘発時の症状スコア

\begin{tabular}{|c|c|c|c|}
\hline No. & group & $\begin{array}{l}\text { symptom } \\
\text { score }\end{array}$ & sensitization \\
\hline 1 & $\mathrm{D}$ & 5 & $(+)$ \\
\hline 2 & " & 3 & $(+)$ \\
\hline 3 & " & 4 & $(+)$ \\
\hline 4 & "I & 5 & $(+)$ \\
\hline 5 & " & 3 & $(+)$ \\
\hline 6 & " & 4 & $(+)$ \\
\hline 7 & $\mathrm{E}$ & 0 & $(-)$ \\
\hline 8 & " & 2 & $(+)$ \\
\hline 9 & "I & 2 & $(+)$ \\
\hline 10 & " & 1 & $(-)$ \\
\hline 11 & $\mathrm{~F}$ & 3 & $(t)$ \\
\hline 12 & " & 2 & $(+)$ \\
\hline 13 & " & 1 & $(-)$ \\
\hline 14 & " & 0 & $(-)$ \\
\hline $\begin{array}{l}\mathrm{D}: \\
\mathrm{E}: \\
\mathrm{F}:\end{array}$ & $\begin{array}{l}\text { 神経節 } \\
\text { 頸部切 } \\
\text { なし }\end{array}$ & & \\
\hline
\end{tabular}

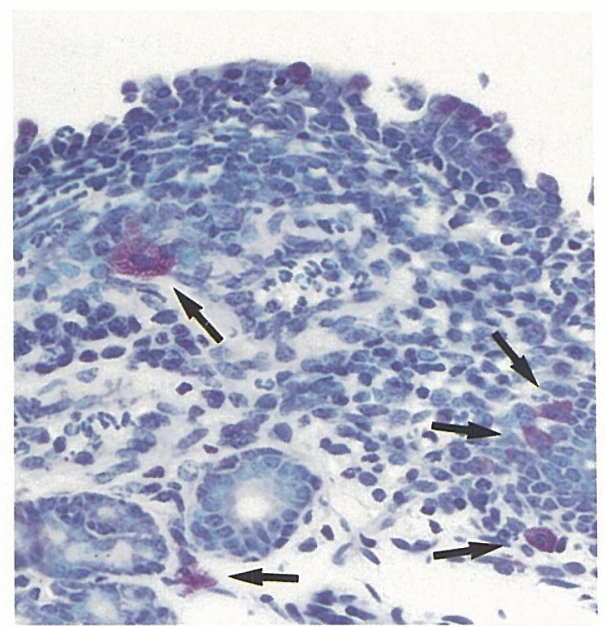

b. カルノフスキー固定

図 5 TDI モルモット（C群）鼻粘膜組織 トルイジンブルー染色 $\times 400$

b. カルノフスキー固定で異染性を示す好塩基性細胞（矢印）が目立つ. 
カルノフスキー固定でよく異染性を示すという 興味ある結果を得た。近年好塩基性顆粒を持っ た細胞には少なくとあ 3 種類考えられている. 1 つは血中を流れている好塩基球であり, 組織 中にある肥満細胞には 2 種類のタイプが示さ れた. ラット，ママスの研究 14) 16) で腸管粘 膜固有層あるいは上皮内に存在する肥満細胞は mucosal mast cell (MMC) と言われ，皮膚や腹 膜などに存在する肥満細胞 (connective tissue mast cell, CTMC) と異なり，ホルマリン液に よる固定で顆粒が染まらず， compound 48/80 や D.S.C.G. にも感受性が低(特徵17) 18) を有し ている.ヒト鼻アレルギーに执いて Okuda ら ${ }^{19}$ は鼻汁には主に好塩基球が存在し，粘膜上皮層 には上記の特徴を示す MMC が多いことを示 した。 さらに鼻粘膜粘液層と上皮層に遊出する 好塩基球と肥満細胞が，主に鼻アレルギーにお けるアレルギー反応に関与する可能性があると 考えられている。乙ていらラット，マウス，ヒ トなどの鼻粘膜における好塩基性細胞について の検索からみると, 今回の TDI モルモット鼻 粘膜に出現した好塩基細胞は固定液による異染 性の違いから MMC としての性格が強いと考 えられた。

鼻粘膜ヒスタミン含有量について TDI モル モットでは正常例に比較して有意に高い值を示 した. Tanaka らの報告20)では10\%TDI 5 日間 塗布 1 クールでは，鼻粘膜ヒスタミン含有量は コントロールと差を認めないが，著者之同様に 2 クールの適用により差を認めている. 組織学 的な好塩基性細胞の出現とヒスタミン量の増加 が平行することがうかがえた，好塩基性細胞か ら遊離したヒスタミンはすぐに不活化されるた め, 組織のヒスタミン含有量は主に細胞内に貯 留するヒスタミン量と考えられる.

Tanaka ら20)は, TDI モルモットではTDIGSA (guinea pig serum albumin) による鼻粘 膜からのヒスタミン遊離能が GSA 単独に比較 して高く, IgG を意味する 4 時間 PCA 反応で 高い陽性率を示し, $\operatorname{IgE}$ を意味する 7 日間 PCA
反応で陽性を示す例のあるととより, IgG だけ でなく IgE の関与が示唆され，組織所見だけ でなくこれらの面からあ鼻アレルギーとしての 性格が強いと報告している.

一方 TDI 喘息患者では気道過敏性の亢進し ていることはメサコリン，メコリール，ヒスタ ミンなどによる過敏性試験で報告 ${ }^{21)}$ 23)されて おり, TDI の曝露が少なくとも気道の過敏性を 亢進させ得ることはほぼ確かであると考えられ ている。しかしその機序については刺激性によ るものか，アレルギー反応を介するかは議論の あるところである．自律神経系に直接作用する という考え ${ }^{2425) て ゙ は ~} \beta$ 遮断説あるいは cholinergic receptor, $\alpha$-adrenergic receptor の過反 応説がある。ささらにまた, TDI の上皮障害によ り露出した知覚神経への直接の刺激による気道 の過反応なども考えられる.アレルギー反応に ついては, TDI がハプテンとして気道粘膜の蛋 白質と結合することによって抗原として作用す ると考えられているが26) 28)，ヒトでは TDI を使用しての皮内反応も陰性が多く, RAST に

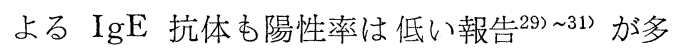
く否定的である. TDI モルモットについては 感作途中から鼻過敏症状の出現を認めたり，5 \%TDI による誘発回数を増せばほぼ全例に気 道過敏症状の出現を認めることから直接の自律 神経に対する化学的反応や，上皮障害による知 覚過敏をむ否定はできない，以上のととから， この TDI モルモットを鼻アレルギーだけでな く，I型アレルギーの関与が少ない血管運動性 鼻炎を含むいわゆるヒトの鼻過敏症のモデルと 考えた。

\section{〈実験結果について>}

基礎実験としてモルモットの上頸神経節の両 側切除を試みたが，すべて死亡したので，今回 の実験では一側の神経節切除を行った。

実験結果をまとめると，モルモットにおいて 上頸神経節切除即ち鼻粘膜の交感神経支配を除 去することにより, TDI に対する鼻過敏症が獲 得されやすくなり，逆にいったん鼻過敏症を獲 
得したモルモットでは，上頸神経節切除即ち交 感神経支配の除去は鼻過敏症状抑制に働いたと いうことである。この結果の解釈として，鼻粘 膜において交感神経支配の除去は副交感神経優 位をむたらし，鼻腺の分泌元進や血管拡張によ る鼻閉の準備状態をつくり，そこへ鼻過敏の原 因となる物質の侵入によって鼻過敏症の獲得が 促されると考えた。一方いったん TDI による 鼻過敏症を獲得したモルモットでは，ヒト鼻過 敏症患者で既に報告9》したように発作期には全 身的な交感神経機能が方進していると推測する 之，鼻局所の交感神経支配の除去は自律神経系 の安定をむたらし鼻過敏症状の抑制につながっ たと考えられる。

TDI 感作モルモット鼻粘膜の自律神経受容 体について久保 ${ }^{32}$ は $\alpha$-adrenergic receptor の 減少を，今野ら ${ }^{33}$ は $\beta$-adrenergic receptor の不 変と muscarinic receptor の増加を報告してい る. TDI モルモットでの全身的な交感神経機 能え進があるとするとその down regulation か ら鼻粘膜の $\alpha_{1}$-receptor の減少がみられたので はないかと推測できる．石部ら ${ }^{34)}$ はモルモット の一側上頸神経節切除後10日では，手術側の鼻 粘膜 $\alpha_{1}$-receptor は denervation supersensitivity により対側に比べて増加するが， $\beta$-receptor, muscarinic receptor は有意な変動はなかっ たと報告した.さらに久保ら ${ }^{35)}$ はTDI モルモッ トでの上頸神経節切除は減少していた $\alpha_{1}$-receptor を増加させ切除前より正常に近づくこと を報告し，病態の改善につながる可能性を示唆 した．本実験での上頸神経節切除による過敏症 状の抑制はこの推測を肯定できる結果と言える.

実験 Iにおいて上頸神経節切除モルモットの 経過を追うと，図 2 に示すごとく 1 週後，いっ たんスコア平均で 2 点以下に症状が扸制される が，それ以後徐々にもとのスコアに戻り，6週 目ではコントロール群とスコアの差も少なくな る傾向を認めている．乙の結果から一側上頸神 経節切除の影響は何らかの形で修復されていく と考えられた。交感神経支配除去後の直接の効
果器側の代償，対側からの代償，あるいは経過 中に神経節そのあのの再生が行われていること などが考えられた。このととが 6 週目の鼻粘膜 組織学的所見とヒスタミン含有量に群間で差を 認めなかった理由と考えられた，明らかな症状 抑制のあった 1 週目の組織所見とヒスタミン含 有量では差を認めたかむしれない，あるいは上 頸神経節切除は鼻粘膜の組織学的な変化や七ス タミン含有量には大きな影響を与えるあのでは ないのかむしれないが，乙れらの点を明らかに するには経過を追った組織の観察，ヒスタミン の測定が必要であろう。

く星状神経節ブロックと Vidian 神経切断術 について>

原因はいずれにしろ，鼻過敏症を持ったヒト， 動物においては自律神経機能に不均衡が生じて いることは確かであり，それがさらに鼻過敏症 状を増強させ悪循環となる，鼻局所の交感神経 支配除去により自律神経の不均衡を是正し悪循 環を断つのが鼻過敏症に対する星状神経節ブロ ックによる治療であると考える，本実験の結果 はこの治療法の効果をある程度支持できるもの であった. Vidian 神経切断術は鼻粘膜の腺や 血管を支配する副交感神経系を遮断し，中枢か らの末梢路を直接断とうとする，より実際的な 治療法677 である。とてろがくしゃみ発作は迷 走神経を介して生じる呼吸筋の運動であり，鼻 アレルギーでは抗原抗体反応の結果遊離された chemical mediator は血管系を直接刺激し，鼻 腺を刺激する可能性あある。乙れらの経路は上 記の 2 つの治療法では断つととはできない，以 上よりこれらの治療は現在のところ鼻過敏症の 原因療法ではなく，自律神経面からの対症療法 であると考える方が妥当であると思われる．適 応や手技の問題については今後臨床応用例を重 ね検討していきたい.

\section{まとめ}

1. $10 \% \mathrm{TDI}$ 酢酸エチル 溶液の鼻塗布によ り鼻過敏症を獲得したモルモットで，鼻粘膜の 組織学的検索とヒスタミン含有量の測定を行っ 
た.

2. 組織学的には, TDI モルモットでは正常 例と比べて分泌機能六進像，上皮直下および上 皮内への著しい好酸球の浸潤と好塩基性細胞の 出現を認めた。 さらに好塩基性細胞はホルマリ ン固定でトルイジンブルー染色により異染性を 示しにくく，粘膜型肥満細胞であることがうか がえた。

3. ヒスタミン含有量は TDI モルモットで は正常例に比較して有意に高值を示した。

4. 正常モルモットで一側上頸神経節を切除 し，TDI にて感作を行うと鼻過敏症が獲得さ れやすく，逆にいったん TDI で鼻過敏症を獲 得したモルモットで一側上頸神経節を切除する ことにより症状の抑制をみた。

5. TDI モルモットで上頸神経節切除後 6 週目の鼻粘膜の組織学的検索とヒスタミン含有 量の測定を行ったが，コントロールに比べて有 意な差を認めなかった。

6. 鼻粘膜における交感神経支配の除去は， 副交感神経優位をむたらし，鼻過敏の準備状態 をつくり，反対にいったん鼻過敏を獲得したモ ルモットでは全身的な交感神経機能の亢進が考 えられ，鼻局所の交感神経支配の除去は自律神 経系の安定をむたらし，過敏症の抑制につなが ったと考察した。

7. 上記の実験結果よりヒトの鼻過敏症に対 する星状神経節ブロック治療は効果を期待でき ることが示唆された。

稿を終えるにあたり終始ご指導，ご校閲を賜った大 阪大学医学部耳鼻咽喉科学教室松永 亨教授, 同荻野 敏講師に心より御礼申し上げます。なお直接実験ので 指導をいただいた同教室原田 保講師ならびにご協力 をいただいた日本臟器製薬株式会社生物活性科学研究 所スタッフの方々に深謝いたします。

本論文の内容は第 218 回日本耳鼻咽喉科学会大阪地 方連合会および第 6 回 ISIAN（東京）において発表 した.

本研究の一部は文部省科学研究費（番号61480358） の援助によった。

\section{文献}

1）奥田 稔：血管運動性鼻炎かアレルギー性鼻炎 か. 鼻アレルギー診療の実際. 23〜33頁, 金原出 版, 東京, 1979 .

2) Hansel FK : Clinical Allergy (chapt 19). pp 386 407, Mosby CV Company, St Louis, 1953.

3) Mygind N : Perennial rhinitis (Chapt 15). pp 224 232, Blackwell scientific publications, Amsterdam, 1978.

4) Kimmelman CP and Ali GHA : Vasomotor rhinitis. Otolaryng Clin North America 19:65 $\sim 71,1986$.

5) Golding-Wood PH : Observations on petrosal and Vidian neurectomy in chronic vasomotor rhinitis. J Laryng $75: 232 \sim 247,1961$.

6) Konno $\mathrm{A}$ and Togawa $\mathrm{K}$ : Vidian neurectomy for allergic rhinitis. Arch Otorhinolaryngol $225: 67 \sim 77,1979$.

7) Konno $\mathrm{A}$ and Togawa $\mathrm{K}$ : Role of the vidian nerve in nasal allergy. Ann Otol $88: 258 \sim 266$, 1979.

8 ）若杉文吉 : 鼻アレルギーの星状神経節ブロック療 法. 日本医事新報 $3130: 24 \sim 27,1984$.

9 ）入船盛弘, 荻野 敏, 荻野 仁, 他: 鼻過敏症患 者の自律神経機能. 耳鼻臨床 $81: 1609 \sim 1616$, 1988.

10）田中健一, 河野茂勝, 川合 満, 他: TDI によ る喘息モデルに観察された鼻アレルギー．アレル ギー $33:$ 199〜206, 1984.

11）入船盛弘, 荻野 敏, 原田 保, 他: モデル動物 による鼻アレルギーの検討（第 1 報）一ヒスタミ ン加免疫グロブリンの効果と組織ヒスタミン含有 量一. 耳鼻臨床 $79: 143 \sim 149,1986$.

12) Hasegawa M, Saito $Y$, Kiyoi M, et al : Seasonal variations of total histamine in patients with seasonal allergic rhinitis. Clin Allergy $13: 277 \sim$ 286, 1983.

13) Shore PA, Burkhalter A and Cohn VH : A method for the fluorometric assay of histamine in tissues. J Pharmacol Exp Ther $127: 182 \sim 186$, 1959.

14) Miller HRP : The structure, origin, and function of mucosal mast cell. A brief review Biol Cell $39: 229 \sim 232,1980$. 
15) Enerback L: The gut mucosal mast cell. Monogr Allergy $17: 407 \sim 412,1982$.

16) Bienstock J, Befus AD, Pearce F, et al : Mast cell heterogenity; derivation and function with emphasis on the intestine. J Allergy Clin Immunol $70: 407 \sim 412,1982$.

17) Befus $\mathrm{AD}$, et al : Mucosal mast cells I Isolation and functional characteristics of rat intestinal mast cells. J Immunol $128: 2475 \sim 2480,1982$.

18) Pearce FL, et al : Mucosal mast cells II effects of antiallergic compounds on histamine secretion by isolated intestinal mast cells. J Immunol $128: 2481 \sim 2486,1982$.

19) Okuda M, Ohtsuka $H$ and Kawabori $S$ : Basophil leukocytes and mast cells in the nose. Eur J Respir Dis $64: 7 \sim 14,1983$.

20) Tanaka K, Kohno S, Kawai M, et al : A nasal allergy model developed in the guinea pig by intranasal application of 2.4-Toluene Diisocyanate. Int Archs Allergy appl Immun 85 : 392 397, 1988.

21) Butcher BT, Salvaggio JE, O'Neil CE, et al : Toluene diisocyanate pulmonaly disease; immunopharmacologic and mecholyl challenge studies. J Allergy Clin Immun $59: 223 \sim 227$, 1977.

22) Butcher BT, et al : Inhalation challenge and pharmacologic studies of TDI sensitive worker. J Allergy Clin Immunol 64 : 146 152, 1979.

23) Gandevia B : Studies of ventilatory capacity and histamine response during exposure to isocyanate vapour in polyurethane form manufacture. Brit $\mathrm{J}$ Indust Med $20: 204 \sim 209,1963$.

24) Davies RJ, et al : The in vitro effect of TDI on lymphocyte cyclic adenosine monophosphate production by isoproterenol, prostaglandin and histamine. J Allergy Clin Immun $60: 223 \sim 229$, 1977.
25) VanERT M and Battigelli MC : Mechanism of respiratory injury by TDI. Annals of Allergy $35: 142 \sim 147,1975$.

26) Karol $\mathrm{MH}$, et al : Tolyl specific IgE antibodies in workers with hypersensitivity to TDI. Am Ind Hyg Assoc J 39:454 458, 1978.

27) Taylor $G$ : Immune responses to TDI exposure in man. Proc Roy Soc Med $63: 379 \sim 380,1979$.

28) Ted Tse CS, Bernstein IL, et al : Induction of murine reaginic antibodies by toluene diisocyanate; an animal model of immediate hypersensitivity reactions to isocyanates. Am $\operatorname{Re} \operatorname{Resp}$ Dis $120: 829 \sim 835,1979$.

29) Butcher BT, et al : Radioallergosorbent testing with p-tolyl monoisocyanate in TDI workers. Clinical Allergy $13: 31 \sim 34,1983$.

30) Danks JM, et al : TDI induced asthma ; evaluation of antibodies in the serum of affected workers against a tolyl mono-isocyanate protein conjugate. Clinical Allergy $11: 161 \sim 168,1981$.

31) Game CJA : Australian TDI workers' sera assayed for $\mathrm{IgE}$ against a $\mathrm{p}$-tolyl-isocyanate-human serum albumin conjugate. Am Ind Hyg Assoc J $43: 759 \sim 763,1982$.

32）久保伸夫：鼻粘膜における薬物受容体の検討. 日 本鼻科学会誌 $22: 346 \sim 352,1983$.

33）今野昭義, 寺田修久：鼻アレルギーと鼻粘膜自律 神経受容体. 耳鼻 $31: 1263 \sim 1283 ， 1985$.

34) 石部 司, 他：上頸神経節摘出後の鼻粘膜自律神 経受容体の変化について. 日本鼻科学会誌 24 : 202 203, 1985.

35）久保伸夫, 他 : 頸部交感神経切除の実験的鼻過敏 症に及ぼす効果. 日本鼻科学会誌 $26: 146 〜 147$, 1987.

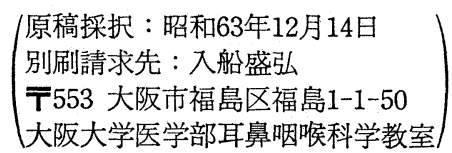

